\title{
Energia Nuclear, Mitos e Realidades
}

\author{
Jaime Oliveira e Eduardo Martinho; Editor: O Mirante, Santarém, 2000
}

\author{
A N TÓNIO PIRES DE MATOS*
}

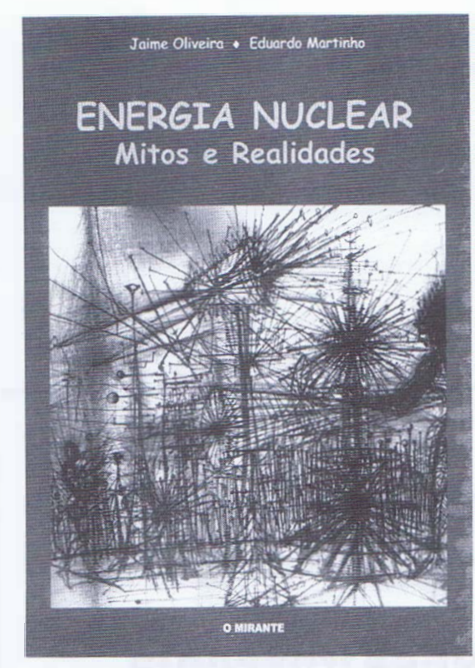

$\mathrm{P}$ ELA PRIMEIRA VEZ É PUBLICADO EM língua portuguesa um livro sobre um tema, a energia nuclear, que, citando o prefácio de António Manuel Baptista, "vai continuar a ser actual e deve saudar-se o aparecimento deste livro como sinal de sanidade e da convicção de que pela ignorância não se chega a nenhum lado onde valha a pena ir". Os autores são ambos investigadores do Instituto Tecnológico e Nuclear.

A quase inexistência nas nossas Universidades de disciplinas de radioquímica e quase nenhum conhecimento de temas relacionados com as ciências nucleares, torna-nos na realidade ignorantes, em particular em matérias que são actuais nomeadamente com implicações em áreas tão importantes como a energia, a bioquímica, o ambiente. a medicina nuclear e a arqueologia.

Este livro, além de abordar um tema polémico, serve como manual de aprendizagem de diversos temas importantes quer para alunos e professores do ensi- no secundário e universitário, quer para um público mais vasto.

Façamos uma descrição tão detalhada, tanto quanto esta breve recensão permita, dos assuntos tratados. No primeiro capítulo é abordado o tema "A energia num mundo finito" e inclui uma análise do consumo mundial de energia primária nas mais diversas formas. No Capítulo II é introduzido o tema "Estrutura dos Átomos" e uma explicação simples do que são os átomos e moléculas, a descoberta do electrão, a teoria do núcleo atómico, a descoberta do neutrão, o que são os nuclidos, e a organização da matéria. Os textos são acompanhados pelos aspectos históricos sendo citados cientistas cuja contribuição foi notável para o avanço da ciência, citando entre outros nomes como Wilhelm Röngten, Antoine-Henri Becquerel, Marie e Pierre Curie, Ernest Rutherford e James Chadwick.

No Capítulo III, a cisão nuclear é explicada com ilustrações bastante sugestivas, e novamente os aspectos históricos citam nomes como Albert Einstein, J. Robert Openheimer, Enrico Fermi, Lise Meitner, e Otio Hahn. São descritos vários tipos de centrais nucleares e o ciclo do combustivel nuclear desde a extracção do minério até ao reprocessamento do combustivel e sua armazenagem.

No Capítulo IV é abordada a Fusão Nuclear, a sua evolução histórica, como funciona um reactor de fusão e uma breve nota sobre os problemas tecnológicos a resolver.

O Capítulo V, "Radiações Ionizantes", começa com a explicação do que é a radioactividade sendo descritos em seguida vários tipos de transformações radioactivas e as radiações ionizantes alfa, beta, gama e raios X. O Capítulo termina com uma breve nota sobre a exposição do homem às radiações e um exemplo sugestivo da dose média recebida pela população do Reino Unido e de Portugal.

O último Capítulo, "O Nuclear, o Homem e o Ambiente" trata dos efeitos biológicos das radiações ionizantes, da protecção contra radiações e da segurança das centrais nucleares. A problemática dos resíduos radioactivos e a sua gestão terminam este livro.

Um glossário e elementos biográficos anexos são bastante úteis, em particular, para quem ensina

Este livro além de estar escrito numa linguagem científica simples e simultaneamente rigorosa, e com um estilo linguistico impecável, é acompanhado de fotografias e ilustrações, que além de explicarem o texto, o tornam agradável de ler. Deve-se esse trabalho ao colega do Instituto Tecnológico e Nuclear, António Falcão.

Talvez a publicação deste livro estimule outros potenciais autores a escrever um livro sobre radioquimica, que tanta falta faz no nosso meio escolar.

Concluindo, a publicação deste livro é uma importante contribuição para a divulgação das ciências nucleares, para o aumento da cultura científica de alunos e professores do ensino secundário e universitário. É util a existência desta obra em qualquer biblioteca. 